\title{
Languages in Contact - Some Results of Research at Albanian University Students in Italy
}

\author{
Prof. Gjilda Alimhilli Prendushi \\ Albanian Language and Literature \\ University of Bari "Aldo Moro" (Italy)
}

\section{Abstract}

This work is the result of personal observations of university Albanian students' studying Albanian language, with different times of residence in Italy, and contact between the Albanian and Italian language, too. My contacts with the students are grouped in two situations: those at work as lectures, seminars, receptions and examinations, and casual. It can be seen big differences in the use of two languages in these different situations. In the first group, at work, the use of the Albanian language is certainly much more correct and various forms of "mixing" almost non-existent. In the second group, especially among people very close or in the presence of Italian friends, it can be seen immediately code changes between Albanian and Italian. The communication code changing is under the influence of various factors. It is clear that reference students use Italian for formal use, for example, in their communications with teachers, while the Albanian in informal situations as at home and more. Thus, the choice of language is influenced by situational factors, like the stylistic choices that people make in a single language. Moreover, they with the language choice can move and change the tone of a situation, from formal to informal, too. These situations encountered made the basis for beginning the study. The examples cited in this paper are collected and classified, in accordance with the standard methodology, into various groups according to the probable cause for the change of the code of communication: Code changes used mainly in Italy but also in Albania; Code changes related to technology; Code changes related to the pronunciation; Code changes related to the characteristics of the country where they stay; Translations. Certainly, this first phase of research has shown the clear presence of code changes in the Albanian language. These phenomena are of various types and of varying importance: in a group of individuals it is a strong influence of the territory, Italy, for this reason we can presume that, back in Albania, the students will lose it; in another group of individuals it seems that it could turn, maybe, into loans. The last category includes some words that reflect deficiencies in the lexicon of the Albanian language, but also others that may gain ground thanks to their peculiarities. The results presented in this work should not be generalized, they only aspire to expand our understanding to the linguistic and social phenomena of contact between two languages such as Albanian and Italian, and in general, on the subject of bilingualism and the effects of the stay for a long time in Italy of Albanian people.

Keywords: Languages in Contact - Some Results of Research at Albanian University Students in Italy

\section{Introduction}

One of the main objectives of the people residing in a country other than their own (for immigration, study, and temporary work or other) is the balance between the use of their own language and that of the country that hosts them.

This situation is known by the sociolinguistic phenomenon of "bilingualism", or, when there are more than two languages, as "multilingualism".

This article will use the term "bilingualism", referring to the general situation, such as using more than one language.

Often, the bilingual community unknowingly uses different languages in different contexts: one language at home, a different one at the road, in the workplace or in the study or even a language with older family members and another with young people. It is estimated that the half of the world's population is bilingual, which means that their daily life is characterized by a continuous movement between two or more languages. The numbers are increasing rapidly; this is due to an increase in international immigration. 
The object of the research it is the influence of the Italian language on a part of the Albanian community in Italy and their language. This community was created starting from about a quarter of century ago ${ }^{1}$.

The study on bilingualism can comprise different linguistic phenomena. One of these concerns the linguistic communities ${ }^{2}$, on which you could make a number of questions: what is the relative position of the different languages in a bilingual society, and how this is changing? Another aspect may relate to the individual speaker who is bilingual "What effect does bilingualism on language users, in particular on the method in which they use the languages? ". Finally, the language itself can become an object of study "What happens to languages which are 'in contact', that is, spoken in the same community? How do they influence each other?"

This article will focus the attention on the third perspective, which is the language itself as the object of the study. In an extensive personal study project, the survey was directed towards the linguistic effects and individual bilingualism due to several reasons (residence, immigration or other), are been observed the Albanian students of university ${ }^{3}$ of linguistic address. The results presented should not be generalized, they only aspire to expand our understanding of this particular group, and the linguistic and social phenomena of contact between the two languages, Albanian and Italian, and in general to the issue of bilingualism and the effects of staying for a long time in Italy. There will be presented some examples about the spoken Albanian, whose linguistic phenomena are analyzed according to a standard classification.

INDIVIDUAL BILINGUALISM AND THE CODE CHANGINGS

The bilingual individual, in everyday use, continuously separate the two codes of communication. In general, bilinguals make a clear separation of functions, by using the two languages in different situations. Various factors in a conversation, such as the subject, the interlocutor and the location, may influence the choice of modes and the use of language 4 .

Do bilinguals succeed in keeping separate the two languages? For some bilingual the answer is yes, for others it is not. When in the language $A$ enters elements of language $B$, the phenomenon is called changing of code ${ }^{5}$.

The contact between the languages is the basis of the testing of various linguistic phenomena in a community. Some of these linguistic phenomena are the interference and other socio-linguistic concepts as bilingualism, code switching and code mixing. Such concepts are relatively associated with the language interference. It is necessary to clarify the phenomenon of interference that may come up in bilinguals. Interference is the transfer of elements from one language to one other in various linguistic levels; that is, what leads to the high incidence of switching and mixing of code in bilinguals. When the code changes, switching of code and mixing of code, occur to compensate for difficulties in language we can see them as interference, but not when they are used as a sociolinguistic instrument.

Briefly, code-switching is defined as the alternation of language that occurs between sentences, instead of within the phrases. More specifically, the code switching can be defined as the intersentence alternation of languages within a single expression or speech. In this case also there are included the exclamations at both ends of the phrase.

The code mixing is defined as the alternation of two or more languages within a sentence. The code mixing is understood as a process of insertion of a different lexical category, stranger, in a given structure.

The distinction between code-switching and code mixing can be correlated to the formalities of the situation. The code mixing occurs in less formal situation, while the code-switching occurs in a more formal situation.

\footnotetext{
1 Italian municipalities (http://www.comuni-italiani.it/statistiche/stranieri/al.html), shows that in 2012 in Italy there are 464,962 Albanian immigrants.

Baker, A.,Hengeveld, K. (2012: 404-407).

${ }_{3}$ OSCE, The report Almalaurea (2014 (http://www.ilfattoquotidiano.it/2014/11/05/universita-calano-gli-italiani-iscritti-aumentano-glistranieri-albania-cina-in-testa/1192557/), it appears that in the Italian universities were registered 7300 foreigners, $16 \%$ of which Albanians then the Chinese with $9 \%$. In the same report states that: "The graduates with foreign citizenship are registered to the linguistic faculties, in medicine, economics and architecture."

4 In http://www.lingref.com/isb/4/110ISB4.PDF

${ }^{5}$ Filippi, R., Leech, R., Thomas, M. S., Green, D. W., \& Dick, F. (2012: 858-872).
} 
It is clear that students, taken as reference, use Italian for formal use, for example, in their communications with the professors, while the Albanian in informal situations as at home and more. So, the choice of language is influenced by situational factors, just like with the stylistic choices that people make in a single language.

More important, with their choice towards a particular language they can move and change the tone in a situation, from formal to informal.

In the course of a single conversation you can observe the alternation of languages. That is, you will have a change of communication code. We have encountered this situation in mixed groups, Italian and Albanian students, but sometimes in groups with just Albanian students. At following are presented some examples, collected and classified into various groups. This was done according to the probable cause ${ }^{1}$ of the code change in the communication.

\section{GREETINGS USED MAINLY IN ITALY BUT AS WELL IN ALBANIA}

Some of these cases of change and code switching involves unique words such as ciao/ salve and other regards, generally linked to the Italian context in which the conversation takes place. But, as we shall see, for these words would be equally possible to choose an equivalent in Albanian. We very often come across the use of (1) ciao in place of mirupafshim, mirëdita or mirëmbrëma, etc. And also (2) salve, whose correspondent in Albanian is përshëndetje. This greeting is also used in situations where had to be used mirëdita or mirëmbrëma, etc. The word ciao is entered in use on many occasions also in Albania, perhaps mainly in large cities as an element of modernity or simply for its short form, a social factor called "economy of language2", particularly worthy of mention in the technology, in mobile telephony. Another expression that we found usually used from the students was (3) grazie. It was used often during informal conversations.

In the examples (1), (2) and (3), we observe the insertion of a single word from one language, in this case the Italian, in a sentence in a different language, the Albanian. These types of change of code, code-switching, can be accidental. But if this happens more often at random, with the time it can also turn into loan, becoming stable in the language lexicon. In bilingual contexts, the line between the lexical loan and the forms of the code change is, at times, difficult to delineate. Indeed, the lexical borrowing process is finalized when a loanword is listed in a dictionary. Actually we are, surely, far away, from this transformation. However, in the future research we will try to distinguish between occurrences just for a time (for example, cases of change of code, in its forms) and the elements that are entered at the level of a group and can therefore be called "loanwords" .

Another example is the exclamation (4) brava: $E$ bëre edhe këtë punë. Brava! It turns out to be a dialogue between two Albanian students who express themselves properly, using a single good Italian word (in Albanian të lumtë) in the middle of the speech. It is a clear case of code-switching.

\section{CODE CHANGING RELATED TO THE TECHNOLOGY3}

When a new product arrives or a new concept is adopted, the word 4 may come, too. A large number of speakers of a second language, users of the product or of the concept, can be the source of this contact between two languages, and therefore the source of change of the main language, the Albanian in our case, also in its territory. When one or more speakers are starting to adopt foreign elements in a speech and this process acquires a systemic character, the original language will be changed. In this way there is been a shift from interference to borrowing of an element from the language $A$ to the language B. At the lexical level, this loan of words from another language usually has cultural aspect and/or/even a technological one, as we will see later in the example of the computer printer.

Now we discuss about the loan and the code mixing in the Albanian language. With the commencement of the computers in Albania it happened, as had already happened in other countries, the temporal separation between the time of writing and that of the material printing of a document. With the typewriter the writing and the printing coincide and the term used

\footnotetext{
1 Bista, K. (2010: 1-19).

2 See. Vicentini (2003): 37-57), Words 3: The economy principle in language.

${ }^{3}$ Poplack, Sh. D. (1988: 47-104).

${ }^{4}$ See. Hock (1996: 271). First of all, every time that speakers of a language are in contact with "new cultural objects, new religious and technical concepts, or references abroad, with the fauna and flora, there is obviously a need for a vocabulary to express these concepts or references". Second, very often the highest prestige of the donor language, generally or in parts, is the motivation for the loans.
} 
was typing, Albanian shtyp. With the computer first is written and then, without any time limit, the printing. And it is this term in particular, related to the printer of the computer, which was missing in Albanian. The word exists in Albania in reference to press or to printing in typography. The entrance of the new technology introduced a new English term, that as trend or simply tied to a practical factor (at the printer's packaging was written Printer), at the current Albanian vocabulary: (5) Sot e printova raportin. While, the students in question are expressed in this way: (6) Sapo e stampova lauren. Më doli shumë e bukur.

In the first sentence we see the use of two words certainly coming from the Italian language. The word which arouses the interest is stampova, clearly linked to the printer and the printing. Here there is been a new change of code, code mixing, and it is replaced by a new word with the Albanian ending, an Anglo-Saxon loan in Albanian, belonging to the language of the majority in which speakers stay. This could be an example of an initial morphological assimilation of an Italian word, a verb, in Albanian dictionaries. In Albanian, as in other languages, the main part of morphologically assimilated words also turns out to be the nouns and the verbs.

\section{CODE CHANGING RELATED TO SPELLING}

Another interesting factor is the reading by the Italian pronunciation rule of the words that exist in the Albanian language (always linked with the world of technology). An obvious case is the term sms, the electronic messaging via mobile phones. Both in Albania and in Italy the code exists in the same form and in both cases is an Anglo-Saxon loan (SMS - Short Message Service). The difference is in how they are pronounced the letters that makes up: Albanian ' $s$ " $m$ " $s$ ", according to the Albanian spelling rule, while in Italian 'esse "eme "esse" according to the rule of Italian spelling. Also in this case we encountered another change of code. Listening carefully to students, the pronunciation of the acronym is by the Italian spelling, that is the language of the majority in the territory.

Technology is always the one that, perhaps, influences more in the change ${ }^{1}$ of the language. We will present another example related to new technologies, the reading of an e-mail address in Albanian and in Italian: (8) arben@gmail.com, in Albanian reads arben 'et' $\mathrm{g}$ meil. kom, in Italian reads arben 'chiocciola' gi meil. com. The difference in reading is due to the pronunciation of the identifying symbol of e-mail (@). Almost all students, even when pronounce the e-mail in Albanian, do not use more the English pronunciation "at" but chiocciola (the snail) Italian pronunciation (speaking in Albanian should be kioçola and so in writing). Also in this case there has been a code-switching. Moreover it seems that in spelling it verbally, by telephone or otherwise, the use of Italian spelling results clearer than "at", thus decreasing the chances of mistakes in the e-mail address transmission. It would appear that we are heading towards a convenience loan. This is because of the massive Albanian immigrants in Italy and the continuous exchanges.

\section{CODE CHANGING RELATED TO THE CHARACTERISTICS OF THE COUNTRY IN WHICH RESIDES}

A further change of code found is the use of the term laurea, who joined the Albanian language with a new meaning and is used according to the Albanian grammar rules. In this case the term is lent to the Albanian language.

We analyze the previous example: (7) Sapo e stampova lauren. Më doli shumë e bukur. This is a clear case of interference; the term laurea was missing in the Albanian language. But in the sentence there are two words assimilated morphologically: stampova, previously analyzed, and lauren ("graduation" in Italian). The latter term is a loan of necessary and prestige. The word in question does not exist in Albanian ${ }^{2}$ and is certainly linked to the Italian reality. Its correspondent in Albania is the university degree. The students in question are attaining a university degree in Italy, where such degree is called laurea, so it is natural to use the Italian word and then deliver it in the Albanian language system. This is also established through an encounter with former graduate students in Italy, who speaking about their university degree declared jam lauruar "I'm graduated". Certainly, to the need of expression with the new term, it is also annexed the prestige that it inherently carries.

In addition, remaining in the laurea area there is another sentence where you could clearly see the code mixing, (8) Sot $u$ laurova con 110 e lode. The term reflects the difference of the Italian university evaluation system: 110 is the maximum

\footnotetext{
1 See Daulton (2011): Prestito lessicale e la global web delle parole. In http://repo.lib.ryukoku.ac.jp/jspui/bitstream/10519/1290/1/r-ky_033_01_004.pdf

2 See Fjalori i gjuhës së sotme (1984:595) for the meaning of this term.
} 
rating of the Italian degree, while an Albanian university degree its counterpart is 10 . This change of code could be linked to the territory, for this reason its future in Albania is by no means certain.

\section{CONSIDERATIONS}

In this paragraph will be present some considerations, but not conclusions.

The research, having been conducted on a small group of persons, was intended as for the basis of a larger study. In addition, the analysis is conducted through some personal notes resulting from open conversations, undocumented, but only transcribed by the author.

In the future, surely, they will be used ways and means to document what of interest. In any case, the first phase of the research has demonstrated a clear presence of changes of the Albanian language code and interferences. These phenomena are of various types and each of them has its own significance: in a group of these changing there is a strong influence of the territory, for this reason, it can be assumed that once back in Albania, students will lose it; in another group it looks like they could be turned into loans, this will lead to the graft of some words that reflect deficiencies in the lexicon of the Albanian language, but also of others which would gain territory thanks to their peculiarities.

\section{Bibliography}

[1] Ariffin, K., Rafik-Galea, S. (2009), Code-switching as a communication device in conversation, Language \& Society Newsletter, 5.

[2] Baker, A.,Hengeveld, K. (2012), Linguistics: The Basics, John Wiley \& Sons, 404-407.

[3] Bista, K. (2010), Factors of Code Switching among Bilingual English Students in the University Classroom: A Survey, Online Submission, 9(29), 1-19.

[4] Chini, M. (2004), Plurilinguismo e immigrazione in Italia. Un'indagine sociolinguistica a Pavia e Torino, Milano, Editore: Franco Angeli.

[5] Choy, W. F. (2011), Functions and reasons for code-switching on facebook by UTAR English-Mandarin Chinese bilingual undergraduates (Doctoral dissertation, UTAR).

[6] Desmet, T., Duyck, W. (2007), Bilingual language processing, Language and linguistics compass, 1(3), 168194.

[7] Filippi, R., Leech, R., Thomas, M. S., Green, D. W., \& Dick, F. (2012, 12), A bilingual advantage in controlling language interference during sentence comprehension, Bilingualism: Language and Cognition, 15(04), 858-872, doi: $10.1017 / S 1366728911000708$.

[8] Filippi, R., Morris, J., Richardson, F. M., Bright, P.,Thomas, M. S., Karmiloff-Smith, A., Marian, 7.V. (2015), Bilingual children show an advantage in controlling verbal interference during spoken language comprehension,Bilingualism: Language and Cognition, 18(03), 490-501.

[9] Grant-Russell, P., Beaudet, C. (1999), Lexical borrowings from French in written Quebec English, University of Pennsylvania Working Papers in Linguistics, 6(2), 3.

[10] Lipski, J. (2005), Code-switching or borrowing? No sé so no puedo decir, you know, Selected proceedings of the second workshop on Spanish sociolinguistics, 1-15.

[11] Lipski, J, M. (1976), Structural Linguistics and Bilingual Interference: Problems and Proposals, Linguistics and bilingual education, Jamaica, NY: Bilingual Press.

[12] Hock, H. H., Brian D. J. (1996), Language History, Language Change, and Language Relationship: an Introduction to Historical and Comparative Linguistics, Berlin: Mouton de Gruyter,.

[13] Muysken, P. (2000), Bilingual Speech: a Typology of Code-Mixing, Cambridge, UK: Cambridge University Press.

[14] Myers-Scotton, C. (1993), Duelling Languages: Grammatical Structure in Codeswitching, Oxford, Eng.: Clarendon Press. 
[15] Poplack, S., Sankoff, D., Miller, C. (1988), The social correlates and linguistic processes of lexical borrowing and assimilation, Linguistics, 26(1), 47-104.

[16] Soh, K. C. (2012), Bilingual testing at the phrase and text levels and its implications for bilingual programmes, Linguistics and Language Teaching, Volume 3, Issue 2, 249-264.

[17] Shkurtaj, Gj. (2009), Përzierja e kodeve dhe prishja e kodeve, Sociolinguistikë e shqipes,Tiranë, Shtëpia Botuese MORAVA, 322-342.

[18] Urdaneta, J. L. L. (2011), Spanish-English writing structure interferences in second language learners, GIST Education and Learning Research Journal, Volume 5, 158-179.

[19] Vicentini, A. (2003), Notes and Observations from early modern english grammars, The economy principle in language, Mots, Palabras, Words, Volume 3, 37-57. 